\title{
Sjuksköterskors berättelser om rädsla inom psykiatrisk vård före moderna psykofarmaka
}

\author{
GUNNEL SVEDBERG
}

\begin{abstract}
Rädsla är ett återkommande tema vid intervjuer med sjuksköterskor som arbetat inom sinnessjukvård under 1940-talet. Föreställningar och erfarenheter förmedlas i berättelserna om rädslans uttryck och konsekvenser, liksom sätten att hantera den egna rädslan.
\end{abstract}

\begin{abstract}
Denna artikel behandlar rädsla hos omvårdnadspersonal inom svensk sinnessjukvård före 1953. Efter denna tidpunkt infördes allmänt på svenska sinnessjukhus den typ av läkemedel som nu benämns "neuroleptika" eller "moderna psykofarmaka». Detta betraktades under de närmast följande åren som en vändpunkt eller en "revolution" inom den psykiatriska vården.

I november 1957 kom jag som sjuksköterskeelev till Ulleråkers sjukhus i Uppsala, ett stort statligt sinnessjukhus. En hel värld fylld av förunderligheter, som lockade och skrämde, mötte mig där. Mina försök att förstå bemöttes ofta med ett uppgivet: »Du
\end{abstract}

Gunnel Svedberg är leg.sjuksköterska, leg. psykoterapeut. Doktorand vid Karolinska institutet, klinisk neurovetenskap, psykiatri. Verksam vid Centrum för kvinnoforskning, Stockholms universitet. som inte var med före neuroleptika kan inte begripa hur det var». Vad var det jag inte kunde begripa? Att försöka fånga och förstå något av detta obegripliga ligger bakom ansatsen attstudera omvårdnadstraditioner med hjälp av muntliga och skriftliga berättelser från svensk psykiatrisk vård.

\section{En introduktion till sinnessjukvården under 1940-talet}

Vid slutet av 1940-talet fanns omkring 31000 patienter på svenska statliga och kommunala sinnessjukhus, en utökning av patientantalet från drygt 1000 under ett århundrade. Under samma period hade folkmängden fördubblats. År 1945 skisserade Medicinalstyrelsen i en 10-årsplan en ökning med ytterligare 6300 vårdplatser. I

Socialvetenskaplig tidskrift nr 1-2 2001 
psykiatrisk litteratur beskrevs sinnessjukvården som mitt inne i en livlig omdaningsperiod, men eftersatt i förhållande till standarden vid kroppssjukhusen. Sedan 1931 kunde intagning på sinnessjukhus ske frivilligt, men det stora flertalet patienter var tvångsvårdade under 1940-talet och många patienter hade vid intagningstillfället bedömts som farliga för egen eller andras säkerhet. Omkring 1200 patienter fanns i familjevård under sinnessjukhusens överinseende. Öppenvård fanns i mycket begränsad omfattning. ${ }^{1}$ Det kunde rent av vara en fara i att folk får för mycket tillfälle att syssla med sina krämpor och besvärligheter, anser överläkare John Agerberg vid Frösö sjukhus i Östersund, och förordar en avsevärd utökning av antalet vårdplatser istället för polikliniker och rådgivningsbyråer. ${ }^{2}$

Värdet av institutionsbaserad psykiatrisk vård ifrågasatts på många håll i Europa vid slutet av 1800-talet. I Sverige förordades mer öppna vårdformer och bättre rättssäkerhet $\mathrm{i}$ samband med tvångsvård bland annat av läkaren Anton Nyström. ${ }^{3}$ Men det var först i slutet av 1950-talet som stigmatiseringens mekanismer och hospitaliseringens konsekvenser beskrevs ingående av sociologen Erving Goffman. ${ }^{4}$ Motsvarande fenomen var dock kända och omnämnda i psykiatrisk litteratur. $^{5}$

Det pågående världskriget skymtar $i$ årsberättelser som försvårad personalsituation

1 Lundquist (1949a), 15-18. Sjöström (1992).

2 Agerberg (1949), 361.

3 Nyström (1895). Sjöström(1992), 105-115. Qvarsell (1993), 128-132, 157.

4 Goffman (1961).

5 Bolling (1896), 14. Gadelius (1929), 269. på grund av krigsinkallelser. ${ }^{6}$ Åtskilliga sinnessjukhus klagar över brist på arbetsmaterial för de sjukas sysselsättning. Krigets svårigheter i fråga om livsmedelstillgången har kommit att avspegla sig i patienternas viktkurvor. Männen har i medeltal minskat 4, 5 $\mathrm{kg}$ och kvinnorna 3, $9 \mathrm{~kg}$ under de senaste fyra åren uppges från Malmö Östra sjukhus, men man tror inte att viktminskningen varit större än för befolkningen i gemen. ${ }^{7}$ Sinnessjuka flyktingar måste beredas plats på sinnessjukhusen, som vid Umedalens sjukhus i samband med evakueringen av Nordfinland hösten 1944. ${ }^{8}$ Andelen patienter med smittsamma sjukdomar ökade med »Tbcflyktingar» och »difteribärare».

Årsberättelser och inspektionsberättelser från sinnessjukhusen år 1942 ger intryck av att mekaniska tvångsmedel inte längre används i så stor utsträckning som under föregående årtionden. ${ }^{9}$ Uppgifterna är dock osäkra, eftersom tidigare inspektionsberättelsers sammanställningar i tabellform gällande tvångsmedel under tre månader $\mathrm{i}$ följd, på 40-talet ersatts av redovisningar från den årliga inspektionsdagen. Från några sinnessjukhus innehåller årsberättelser en sammanfattande kommentar om bruket av skyddsmedel. T.ex. uppger Lillhagens sjuk-

6 Medicinalstyrelsens arkiv. Sinnessjukvårdsbyrån. Årsberättelserfrånsinnessjukhusm.fl. 1942. E II a: 28. Psykiatriska sjukhuset i Stockholm.

7 Medicinalstyrelsens arkiv. Sinnessjukvårdsbyrån. Årsberättelserfrånsinnessjukhus m. fl. 1942. E II a: 28. Malmö östra sjukhus, Malmö.

8 Medicinalstyrelsens arkiv. Sinnessjukvårdsbyrån. Årsberättelserfrånsinnessjukhus m. fl. 1942. E II a: 28. Umedalens sjukhus, Umeå.

9 MedicinalstyrelsenSinnessjukvårdsbyrån Överinspektörens berättelser 1938-1942, E II c: 13 A. 
hus i Göteborg år 1942, att mekaniska tvångsmedel har använts i ringa utsträckning, utan att användningen av sedativa läkemedel har behövt ökas. Genom ett vidgat samspel mellan olika terapeutiska medel finns en tendens till ett allmänt och påfallande roläge för de sjuka i jämförelse med tidigare år. $^{10}$

Svensk psykiatri på 1940-talet framstår i samtida litteratur som behandlingsintensiv. De på30-talet nya metoderna elektrochockbehandling och insulinbehandling gavs på alla sinnessjukhus under 1940-talet. Lobotomi, också detta en behandlingsmetod från 30-talet tillämpades i varierande utsträckning på sinnessjukhusen i Sverige. Vid Sidsjöns sjukhus i Sundsvall till exempel, hade över 200 patienter opererats och resultaten bedömdes som mycket uppmuntrande. ${ }^{11}$ Malariabehandling vid neurosyfilis användes alternativt till den nyare hyperthermapparaten. ${ }^{12}$ De läkemedel som fanns tillgängliga bestod av lugnande och sömngivande mediciner och opiumpreparat. Stora doser kontinuerligt tillförda sömnmedel kunde ges som sömnkur under 1 till 2 veckor vid svåra oros- och ångesttillstånd. ${ }^{13}$ Sysselsättningsterapi, betraktades även detta som en

10 Medicinalstyrelsens arkiv. Sinnessjukvårdsbyrån. Årsberättelserfrånsinnessjukhusm.fl. 1942. E II a: 28. Lillhagens sjukhus, Göteborg.

11 Osterman (1949), 352.

12 Båda metoderna innebar bekämpning av syfilisinfektion genom höjning av kroppstemperaturen. Hyperthermapparat införskaffades till S:t Lars sjukhus i slutet av 1945, men föll sönder pga. tekniska brister. Källa: Medicinalstyrelsens arkiv. Sinnessjukvårdsbyrån. Årsberättelser från sinnessjukhus m.fl. 1946. E II a: 32. S:t Lars sjukhus, Lund.

13 Lundquist (1949b), 87-91. behandlingsmetod, som skulle ordineras och doseras av läkare. Det förekom att lämplig sysselsättning framhölls som det viktigaste hjälpmedlet då sjukvården bedrevs efter den moderna regimbehandlingens krav, där en »målmedveten strävan inriktas på att med de sjukas egen medverkan åstadkomma så goda miljöförhållanden som möjligt. . ${ }^{14}$

Hur möjligheter tillsterilisering av patienter ur läkares perspektiv förknippades med humanitet och minskning av bördan av att inom sinnessjukvården onödigtvis tvångsvårda personer, framgår av inspektionsberättelse och årsberättelse från 1930-talet. ${ }^{15}$ Lagen om sterilisering från år 1934 utvidgades år 1941 så att personer som led av sinnessjukdom, sinnesslöhet, svårartad sjukdom eller svårt lyte kunde steriliseras utan eget samtycke, dels av arvshygieniska skäl, dels om personen bedömdes som olämplig för föräldraskap. En övervägande andel av de steriliserade var kvinnor. ${ }^{16}$ Årsberättelser från sinnessjukhusen innehåller korta notiser om steriliseringar. Till exempel uppger Säters sjukhus 1942attfem kvinnliga patienter har steriliserats, varav två imbecilla och tre schizofrena. En kvinna avled i samband med operationen. I ytterligare ett fall fanns tillstånd för sterilisering, gällande en imbecill kvinna med komplicerande schizofreni,

14 Medicinalstyrelsens arkiv. Sinnessjukvårdsbyrån. Årsberättelser från sinnessjukhus m.fl. 1942. E II a: 28. Frösö sjukhus, Östersund.

15 Medicinalstyrelsens arkiv Sinnessjukvårdsbyrån Årsberättelser från sinnessjukhus m. fl. 1932 E II a:18. Västra Mark, Örebro. Medicinalstyrelsens arkiv Sinnessjukvårdsbyrån Överinspektörens berättelser 1932-1933 E II c: 10. Västra Mark, Örebro.

16 Se t.ex.: Runcis, Maija (1998) Steriliseringar $i$ folkhemmet. Stockholm: Ordfront. 
men hon vägrade underkasta sig ingreppet. ${ }^{17}$

De ständiga överbeläggningarna, liksom överläkarnas arbetssituation påtalas återkommande i årsberättelser från sinnessjukhusen. Det rapporteras från S:t Lars sjukhus i Lund att överläkaren svarar för närmare 700 patienter, med ständiga ombyten av läkarvikarier och belastas med omfattande skriv-och expeditionsarbete. ${ }^{18}$

Att den mänskliga miljön för patienterna var torftig på sinnessjukhusen och att personalens möjligheter att ägna intresse och omsorg var begränsad framgår i en utredningen av Medicinalstyrelsen. Personalen anses vara för fåtalig och avvägd huvudsakligen ur säkerhetssynpunkt, så att patienterna icke skadar sig själva och varandra. ${ }^{19}$ Vardagstillvaron på sinnessjukhusen framstår som fylld av vårdpersonalens kamp mot smuts, oordning och hotande kaos. Ur patientjournaler framträder en praktik där kontrollen över sjukhusmiljön och patienterna framstår som något som ständigt måste erövras. Där framträder patienters mer eller mindre aktiva motstånd eller uppgivna anpassning till livsvillkor de inte kunde påverka, och till en vård som för dem sällan förknippades med hopp om lindring eller om bot. ${ }^{20}$

17 Medicinalstyrelsens arkiv. Sinnessjukvårdsbyrån. Årsberättelserfrånsinnessjukhus m. fl. 1942. E II a: 28. Säters sjukhus 1942, sid. 3.

18 Medicinalstyrelsens arkiv. Sinnessjukvårdsbyrån. Årsberättelser från innessjukhus m. fl. 1946. E II a: 32. S:T Lars sjukhus, Lund.

19 Statens sjukhusutredning av år 1943, betänkande IV: Synpunkter och förslag rörande sinnessjukvairden. SOU 1948:37.

20 Jönsson (1998)
Könssegregationen var vid 1940-talet fortfarande strikt genomförd vad gäller patienter. "Mans» och "Kvinns" fanns som rumsliga och kulturella motpoler på ömse sidor om det centrum där manliga läkare företrädde psykiatrin. På „Kvinns», bland de kvinnliga patienterna fanns enbart kvinnlig personal. På „Mans» fanns en kvardröjande tradition alltsedan 1800-talet, att enstaka kvinnor arbetade med vård av somatiskt sjuka manliga patienter på sinnessjukhusen. Vid början av 1900-talet anställdes "skolade sjuksköterskor" som översköterskor på såväl kvinnliga som manliga avdelningar vid några sinnessjukhus. Under mellankrigstiden fördes en internationell medicinsk inomvetenskaplig diskussion om fördelar och nackdelar med kvinnlig personal på avdelningar för män vid sinnessjukhusen. Kvinnors moderliga instinktansågs göra dem mer lämpadeän män för vårdande uppgifter. Omvårdnad definierades som ett kvinnligt verksamhetsområde. Men det fanns betänkligheter mot kvinnlig personal. Det gällde bland annat risker för våld från manliga patienter mot kvinnlig personal och kvinnors förmodade »irriterande erotiska inverkan" på manliga patienter. Ytterligare en komplikation med kvinnor som översköterskor på manliga avdelningar var oppositionen från de underordnade manliga skötarna, vars möjligheter att erhålla högre tjänster minskadeom dessa tjänster iökande omfattning tilldelades sjuksköterskor utbildade vid sjuksköterskeskolor. Sjuksköterskor och skötare konkurrerade alltså om samma tjänster vid denna tid och många utredningsförslag angående framtida utbildningsmodeller och befordringsgång lades fram och förkastades. Motsättningarna mellan grupper 
av skötare och sjuksköterskor, liksom mellan deras respektive fackförbund var påtaglig under 1940-talet. Jämsides med vittnesbörd om intressekonflikter mellan skötare och sjuksköterskor finns många vittnesbörd om gott samarbete mellan alla olika personalkategorier och skildringar av den goda familjelika anda som var utmärkande för den avskilda miljö, där personal av alla kategorier både arbetade och bodde. ${ }^{21}$

\section{Källor, metod och frågeställning}

Mellan åren 1982 till 1993 intervjuades 22 sjuksköterskor med specialutbildning inom psykiatrisk vård, som arbetat inom psykiatrisk vård „före neuroleptika». Arbetsperioden sträckte sig i två fall tillbaka så långt som till slutet av 1920-talet. I ett fall begränsar sig erfarenheterna av psykiatrisk vård till något år före den nya psykofarmakans introduktion. Flertalet berättelser om rädsla, sju stycken, skildrar upplevelser från psykiatrisk vård under 1940-talet. De intervjuade sjuksköterskorna representerar erfarenheter från olika befattningar, från skilda verksamhetsfält inom psykiatri och med geografisk spridning. Intervjuerna fokuserade på sjuksköterskors arbete inom psykiatrisk vård, men gav de intervjuade stor frihet att förmedla vad de själva fann väsentligt. Det visade sig vid genomgång av berättelserna att rädsla var ett ofta återkommande tema. Sjuksköterskorna ville förmedla sina erfarenheter av rädsla.

Kvinnors relationer till psykiskt sjuka män har skildrats i ett antal svenska skönlit-

21 Svedberg (1997). terära verk med referens till tiden omkring sekelskiftet 1900 till 1950-talet. Även dessa berättelser diskuteras i relation till sjuksköterskors utsagor om rädsla. Inte sällan kan skönlitteratur gestalta och begripliggöra mellanmänskliga relationer, inre konflikter, känslor, fantasier, föreställningar och upplevelser $^{22}$. Vissa skönlitterära texter kan till formen efterlikna en psykoanalytisk process - avslöjande och insiktsskapande ${ }^{23}$. Myter, sagor, sägner och legender kan antas spegla sin tids folkligt förankrade föreställningar, samtidigt som de traderar dessa vidare.

Studiens fokus har riktats mot berättelser om upplevelser, erfarenheter och föreställningar om vårdares rädsla i samband med omvårdnad inom psykiatrisk vård. Enstaka berättelser vävs samman med andra teman, såsom patienters rädsla, förekomst av våld mot personal, riskbedömning eller konkreta åtgärder i den yttre miljön för att öka säkerheten. Men det är inte dessa teman som här kommer att följas upp. Både de skönlitterära berättelserna och sjuksköterskornas berättelser användes för att söka kunskap om föreställningar om rädsla i relation till sinnessjuka personer under den aktuella tiden. Utsagorna om rädsla diskuteras avslutningsvis mot bakgrund av facklitteratur om rädsla.

Informanternas utsagor, liksom skönlitteraturen, förstås här som berättelser. Analysmetoden har inspirerats av filosofen Paul Ricoeurs texter omberättandets form, innehåll och funktion samt hans texter om historieskrivningens filosofi och teori. Ricoeur

22 Ricoeur(1993), 205-235. Ricoeur(1976), 12-23, 71-85. Ricoeu r (1988), 99-274.

$23 \operatorname{Holm}$ (1989), 24. 
betraktar psykoanalys som en hermeneutisk metod, en "misstankens hermeneutik", som förutsätter ett aktivt lyssnande också efter latenta budskap, dolda innebörder och konflikter. ${ }^{24}$ Ricoeur beskriver en "narrativ identitet" och menar att både individuell identitet och ett kollektivsidentitet kommer ur berättande, en identitet som utvecklas i och genom kommunikation. ${ }^{25}$

Berättelserna antas referera till upplevd verklighet och betraktas inte som historisk verklighet. ${ }^{26}$ Relativt utförliga citat redovisas för att möjliggöra alternativa tolkningar. Frågeställningen kan sammanfattas: Vilka erfarenheter och föreställningar om rädsla är förknippade med arbete inom psykiatrisk vård "före neuroleptika»?

\section{Sjuksköterskor berättar om rädsla}

Isjuksköterskors berättelser om arbete inom psykiatrisk vård finns rädslans närvaro eller frånvarosomständigtåterkommandeteman. Framförallt är första dagens upplevelser förknippade med rädsla. En berättelse som berör upplevelser 1940 lyder:

Vi kom två stycken till Konradsberg. Den andra eleven kom på den så kallade heloroliga avdelningen, "stormen". Så skulle hon och jag gå och äta och så skulle jag gå och hämta henne, men jag hittade henne inte. Jag gick runt /.../så var det en liten passage och där stod hon, så här,

24 Kristensson Uggla (1994). Ricoeur (1993). Ricoeur (1976). Ricoeur (1988).

25 Kristensson Uggla (1994), 441-449. Ricoeur (1988), 244-249. Ricoeur (1992), 1-25. Ricoeur (1991), 188-199.

26 Spence (1987). Spence (1982). tryckt mot väggen, stel av fasa. Hon blev så vansinnigt rädd, för patienterna, så att hon vågade inte röra sig. Hon var paralyserad av skräck. ${ }^{27}$

Berättelsen fortsätter med egna upplevelser:

Första dagen då de delade mat säger en personal så här: "syster kan ju gå och ge Adamsson". Det var en som låg ensam i ett rum i bälte. /.../ Jag gick ju dit, och jag blev så häpen, då jag kom in i det här rummet, för det fanns ju bara den där sängen! Det fanns ju inget nattygsbord. Jag undrade var jag skulle ställa metallskålen, med en sked i. Jag satte mig på sängkanten och började mata henne. Det var inget märkvärdigt med det. Så gick jag ut och hade den tomma skålen med mig ut. Och då sa dom så här: "matade syster henne?" "Jaa", sa jag. "Hon är farlig, hon bits, henne får man inte gå så närau. Så skrattar de? Nästa gång, så vågade jag ju inte sätta mig på sängkanten och mata henne. /.../ Patienten begrep väl - hon kände ju instinktivt naturligtvis, att jag var inte ett dugg rädd för henne./../ Men, det där visar också, att det betydde hur man var mot dom, med dem. ${ }^{28}$

Det fanns förväntan om farlighet:

På den »halvoroliga», där var det ju bara sängar och celler. Det var ingenting annat. Köket låg utanför avdelningen. Vi hade en ung, svårt sjuk schizofren flicka och hon var ensam i sin cell. Hon hade madrassen på golvet, för hon låg inte på något annat sätt. Hennes mamma kom väldigt ofta och så satt dom två på golvet. Ja, jag vet inte vad mamman talade med flickan om. Utan hon gick ju dit. En gång när den här flickan skulle ut /.../var mamman inte med. Då var det en personal som skulle leda ut henne.

27 Informant 17. Född 1917. Sjuksköterska vid Psykiatriska kliniken vid Karolinska sjukhuset. Senare inom familjevård. Vårdlärare från 1954. 28 Informant 17. 
När hon kom utanför avdelningen, då hade jag köksturen den dagen och det låg en förskärare framme. Och som en blixt, var hon där och tog förskäraren. Men hon gjorde ingenting. Hon ville väl liksom bara hota och personalen tog ju från henne den. Men det är också sådant där som man kommer ihåg. /.../ Man förväntade sig av patienterna att dom skulle vara oroliga och farliga. $^{29}$

Den introduktion som gavs elever och nyanställda bar budskap om vad som kunde vara farligt. En sjuksköterska berättar från S:t Lars sjukhus i Lund år 1942:

Hos föreståndarinnan fick man veta att man inte fick lov att röka på rummet och att man skulle akta sig för patienterna. /.../ Jag gick nog där två månader, då ingick det i mina sysslor att varannan helg tjänstgöra på den s k kvinnliga stormen. /.../ Du som inte varit med om den tiden - man kan inte föreställa sig hur det var om man inte varit med om det! ${ }^{30}$

Sjukhusmiljön, de ständigt närvarande reglerna, rutinerna och föreskrifternabar också de ett budskap om farlighet.

Den första dagen på sjukhuset har jag mycket, mycket gott minne av. Jag skulle gå på kvinnlig intagningsavdelning. /../ Jag kom dit och översköterskan hette syster Anna och förstaskötaren syster Elsa. Det var middagstid och jag skulle gå och äta i personalmatsalen. Det var kålsoppa den dagen och jag glömmer aldrig den kålsoppan, för jag var rädd så jag visste inte till mig. Sen kom vi då tillbaka till avdelningen och patienterna undrade ju vem jag var, dom var som man säger relativt lugna och kunde sitta

29 Informant 17.

30 Informant 22. Född 1918. Sjuksköterska Malmö Östra sjukhus, senare föreståndare vid Psykiatriska kliniken i Uppsala. Vårdlärare under 1950-talet. ner lite i lugn och ro./../ Det allra första jag fick göra var att putsa fönster, sådana där små rutor /.../ och stod på en hög stege. Och då var där en patient som stod under stegen och tittade på mig. Du begriper kanske hur jag kände mig? Sedan, sa syster Anna, att om jag inte hade något annat kunde jag sätta mig ner med patienterna och sy lite tillsamman med dem. Och då fick jag en sax i ett långt, långt bältesband och det skulle jag knyta om livet och ha saxen i fickan./.../ Jag fick inte lämna ut saxen./../ Rädd var jag, så jag skakade. ${ }^{31}$

Tilldelningen av matservis skiktades efter dess potentiella farlighet som vapen.

På den lugna avdelningen var en del patienter som hade porslin. Annars hade man ju ingenting annat än rostfria bunkar och rostfria fat och för de halvoroliga och heloroliga avdelningarna, där var det ju inga patienter som fick äta med kniv och gaffel och inte heller ha porslin, utan där hade man ju muggar och bara skedar. $^{32}$

Vandringssägner framförde sitt budskap om vad som kunde hända:

Som ny elev hade jag fått höra om en mentalsköterska som hittats strypt av en patient. Man var livrädd när man skulle sitta kvällvakt. Då dagpersonalen gick - då var man livrädd! ${ }^{33}$

En sjuksköterska berättar från Långbro sjukhus år 1945:

Mitt första intryck, av ett mentalsjukhus, det

31 Informant 22. Berättelse från elevtiden vid St Lars sjukhus, 1940-tal.

32 Informant 22. St Lars sjukhus vid mitten av 1940-talet.

33 Informant 6. Född 1908. Berättelsen från elevtiden på Ulleråker sjukhus i slutet av 1920-talet. Senare översköterska på Beckomberga sjukhus. 
var lite skrämmande. Jag kom ju ändå till en öppen avdelning, 6:an Mans. Men jag tyckte allting var stort, inlåst och stängt. Även om jag kommit till en öppen avdelning, så var det nycklar överallt man skulle. Jag skulle gå ner till l:an Mans /.../en orolig intagningsavdelning. Det är klart att där var det ju mycket mer väsen. Det lät förskräckligt mycket här på sjukhuset. Skrek och bråkade och när man kom in där, det första nästan jag tänkte på: $\mathrm{O}$, så stora vårdare det är här. Långa, stora karlar. Det var ju ett visst mått dom måste ha för att få börja här. Det var inga småpluttar inte. Och så tyckte man ju då att alla rörde sig på ett ganska konstigt sätt. Man var lite rädd, det var jag faktiskt. Man fick till exempel inte vara ensam på expeditionen. Det måste alltid vara låst, där inne, annars måste man ha vårdare med sig. Vi gick aldrig in på ett rum ensam, för det var ju mycket våld och övergrepp. Det fanns ju inte så mycket lugnande (mediciner). Det gjorde ett skrämmande intryck på mig. Men ändå så kände jag det här, att det var roligt på något sätt. Och jag inbillade mig att man gjorde nytta, i alla fall. ${ }^{34}$

Minnen från 1946 vid Ulleråkers sjukhus som "lasarettselev«:

Jag tyckte det var en kuslig upplevelse att liksom bli instängd på en stormavdelning på det här viset, men det var ju också en slags stolthet att man inte skulle klaga eller tycka det var besvärligt för att inte anses sjåpig och okunnig, utan ta det hela naturligt, som man skulle varit van vid det här. ${ }^{35}$

En sjuksköterska kom våren 1949 som elev till en kvinnlig orolig avdelning vid Långbro sjukhus och konstaterar helt kort:

34 Informant 7. Född 1919. Översköterska vid Långbro sjukhus till pensioneringen.

35 Informant 16. Född 1925. Sjuksköterska vid Psykiatriska kliniken, Akademiska sjukhuset, Uppsala. Senare psykolog.
Och sedan började jag här. För jag blev ju aldrig rädd. Jag tyckte det var ett jobb jag skulle trivas med. ${ }^{36}$

Visade man sig inte rädd, gick det bra:

Många patienter var intagna på farlighetsindikation - inte farliga, men uppfattades som farliga /.../ Det var mycket lite våld man råkade ut för. Visade man sig inte rädd, så gick det bra. Alkoholister kunde vara hotfulla ibland. Om de var påverkade, då tyckte de inte att man hade hemma hos dem att göra. De var ju inte vana att få besök från hospitalet./.../ Jag kan inte påminna mig att något hände... De är inte alls så farliga som den stora allmänheten tror. Personal känner väl till det, enstaka patienter kunde vara oroliga. En och annan är ju våldsam, men då var man ju aldrig ensam. ${ }^{37}$

En sjuksköterska blev översköterska 28 år gammal och berättar om tryggheten $i$ en pålitlig skötarkår:

Jag vet inte om jag hade valmöjligheter, men det var ledigt på I Mans. /.../Jag tyckte det var bra att börja där, med manlig personal och manliga patienter. Det var ju orolig (avdelning), dels intagning och dels dom oroliga långliggarna vi hade här. Jag vet inte om jag funderade så mycket då - det är klart ibland tänkte man: här är jag ensam kvinna på avdelningen. Och det var manlig personal. Men på något sätt - det var självklart. Dels att det skulle vara manlig personal, för att jag upplevde att den typ av patien-

36 Informant 21. Född 1928. 1949 översköterska vid Långbro sjukhus. Vårdlärare från år 1956.

37 Informant 8. Född 1903. 1925 antagen som skötarelev vid Vadstena hospital. Efter sjuksköterskeutbildning översköterska vid kvinnlig kronikeravd i 'Klosterbyggnaden', Vadstena hospital. Senare vid familjevården vid Vadstena hospital. Vid hjälpverksamheten vid Säters sjukhus mellan åren 1943-58. 
ter krävde det. Dels att det skulle vara sjuksköterska på avdelningen, det var ju en kutym på Långbro, det var självklart. Det hade varit så från början. Jag tyckte det stämde på något sätt. Jag upplevde en fast vårdarpersonal som en trygghet för mig. Dom gjorde ju sitt jobb. Dom fanns där hela tiden. ${ }^{38}$

I grund och botten var man rädd.

Jag gick som nattsjuksköterska i början av 50-talet och då var det ju skrik och stoj. På en helorolig avdelning var det aldrig tyst, varken natt eller dag. Det fanns ju alltid några som skrek och någon som bråkade och någon hallucinerade och pratade för sig själv, gestikulerade våldsamt och oroligt. Framförallt var det så också att personalen var av välgrundad orsak rädd för patienterna. På en helorolig avdelning var man rädd och man använde sig alltså av en hel del tvångsmedel, det var ju väldigt många patienter som fick ligga till sängs dygnet runt på grund av sin oro. Låg i bälte. Man tog bara upp dem då de skulle gå på toaletten, bada eller tvätta sig. Sen var det bältet igen. /.../ I grund och botten var man rädd! På grund av att man fick ju någon örfil ibland. En sköterska blev illa biten. Det fanns något i den sköterskan - en inneboende rädsla som väckte aggression. Så var det ju patienternas situation. På de stora salarna var det ju förskräckligt att vara patient. Det fanns en rädsla och ett behov av att kontrollera situationen. ${ }^{39}$

Rutiner och föreställningar häftade fast vid vissa patienter:

Det var slentrian. Man sa: „Det är så svårt. Dom är så oroliga. Det går inte.« Jag minns en kvinna som i ilskan slagit en bricka i huvudet på en

38 Informant 21.

39 Informant 1. Född 1926. Sjuksköterska vid Ulleråker sjukhus från 1952. Senare vårdlärare. sköterska /.../ patienten var stor och stark, om hon låg i vanlig säng med bara bälte bar det iväg med hela sängen då oron kom på henne. Hon låg i golvfast säng, med bälte ända till 60-talet, när översköterskan gick i pension. Sen gick det bra att ta upp henne. Mot översköterskans vilja kunde man inte rubba detta tidigare. /.../ Farmaka tog bort aggressiviteten och man slapp vara rädd för dem./../ Rädslan satt i när det gällde vissa patienter. Och det fanns en stor rädsla där. ${ }^{40}$

På 1960-talet beskrev denna sjuksköterska i samband med en statlig utredning, hur det varit före neuroleptika, då personalen av förklarliga skäl var rädd för patienter. Men statliga skötarförbundets representanter ville inte vara med om denna beskrivning. "Det var ingen som var rädd minsann." Det är inte fint att vara rädd, konstaterar sjuksköterskan. ${ }^{41}$ Med en äldre kollega som förebild, förmedlas hur det ideala förhållningssättet såg ut:

Hon var så ljusblå tyckte vi. Mitt i denna brist på tillgång på allting, så var hon ändå alltid klar över att patienten, den individuella kontakten var det centrala. /.../ Där alla andra var rädda /.../ så visste hon att patienten i sig är inte farlig. Det är miljön och vårt sätt att vara som ofta framkallar oron. ${ }^{42}$

\section{Vad kan utläsas ur berättelserna?}

Vad är det sjuksköterskorna förmedlar genom sina utsagor om rädsla vid sina kontakter med sinnessjukvård? Det första man

\footnotetext{
40 Informant 1.

41 Informant 1.

42 Informant 1.
} 
kan konstatera är att rädsla verkar förknippat med sinnessjukvård, annars skulle inte hälften av alla sjuksköterskor själva välja att ta upp ämnet, som för att förmedla sin uppfattning. För det andra kan noteras att innehållet i utsagorna är mycket olika, i det att sjuksköterskorna närmar sig ämnet utifrån skilda utgångspunkter. Trots detta går det att urskilja ett antal teman och förhållningssätt i berättelserna.

\section{Nybörjarrädsla}

Det finns en förväntansrädsla inför mötet med de sinnessjuka. Detaljrika skildringar av ett skräckfyllt första möte har vi fått av flera sjuksköterskor. Redan den fysiska miljön tycks berätta om farlighet. Patienters utforskande blickar har fastnat i minnet. Mot detta ställs, som kontrast, en fortsatt berättelse med ton av stolthet över att trots allt klara av situationen, att inte vara rädd eller med ett konstaterande att den första stora rädslan saknade verklighetsgrund. Det tycks vara i relation till den egna förmågan att bemästra rädsla, som yrkesval och yrkesstolthet är grundad. "Att kunna vara till nyttau där andra sviktar. En sjuksköterska gör ju uttryckligen en koppling mellan upplevelsen av kuslighet, med en stolthet i att klara av situationen. Indirekt i berättelserna kan vi utläsa att både personal och patienter utsatte den nyanlända personen för prövningar, genom att undanhålla information, eller hota för att skrämmas. Det är som om det var just i mötet med rädslan, som den nykomnas duglighet skulle prövas.

\section{Att bemästra rädslan}

I intervjuerna får vi exempel på olika strategier att handskas med den rädsla, som tycks så oundviklig inom psykiatrisk vård. Dels nämns bruk av tvångsmedel och rutiner avsedda att få kontroll över potentiellt farliga situationer och föremål. Att inte vara ensam med patienter, utan möjlighet att få hjälp av annan personal är ett återkommande tema i berättelserna. Att kunna lita på att annan personal på avdelningen är uppmärksam är något som är viktigt för att känna sig trygg, förmedlar sjuksköterskor i sina berättelser.

Inte oväntat berättar sjuksköterskorna om förändringar i samband med ankomst av neuroleptika. Hur högljuddhet och aggressivitet hos patienterna dämpades och behovet av mekaniska tvångsmedel minskade. Några av sjuksköterskorna ger dock uttryck för besvikelse över att rutiner och förhållningssätt från förr levde kvar. Förväntan om vissa patienters farlighet och därmed rädsla för dem, dröjde sig kvar på ett oberättigat sätt, tycker jag mig kunna utläsa. Vissa patienter tycktes bli stigmatiserade av personalens kvardröjande rädsla. Det verkar ha funnits en tvetydighet i budskapet. Samtidigt som det fanns en uppmaning att inte vara rädd, fanns rädslan påtagligt närvarande, så att hela kollektiv skrämdes upp. Detta kan förstås på så sätt, att en socialt tvingande norm om oräddhet, fick som konsekvens ett regelsystem och förhållningssätt som till ytterlighet avsåg skydda personal från situationer där personalens förmåga att behärska sin rädsla skulle kunna sättas på prov. Rigida system av ritualer och skyddsanordningar beskrivs. 
De förefaller haft funktionen att hålla rädslan borta, på ett närmast magiskt sätt. Det fanns andra intrapsykiska förhållningssätt att undgå rädslans förtärande verkan. Flera sjuksköterskor nämner förnekad rädsla. Av sammanhangen i berättelserna kan vi sluta oss till att det dels kan röra sig om ett medvetet förnekande för "det är inte fint att vara rädd». Men där anas också antagandet om en förnekad, omedveten rädsla.

Några sjuksköterskor pekar på strategier, som med nutida förståelse skulle uttryckas som försök att härbärgera sin egen rädsla. Det gäller att inte visa sig rädd, för då kan det gå illa, verkar vara budskapet i ett par berättelser. I samtida facklitteratur återkommer budskapet formulerat som en uppmaning att inte bli irriterad eller rädd.

Boken Den psykiskt sjuka människan och hennes vård av sjuksköterskan Karin Neuman-Rahn ${ }^{43}$ utkom år 1924 och är en lärobok i psykiatrisk vård. ${ }^{44}$ Den fick goda recensioner i Svensk Sjukskötersketidning ${ }^{45}$ och torde varit allmänt spridd bland sjukvårdslärare, som undervisade i psykiatrisk vård. Boken var skriven $i$ en normativ stil och var väl förankrad i tidens psykiatriska och vårdetiska föreställningsvärld. I avsnittet om orolig patients behandling manar författaren:

Först och främst få vi varken bli irriterade eller rädda, utan uppträda lugnt, behärskat, vänligt och säkert. På detta sätt avväpnas mången gång den rasande redan genom vår blotta sin-

43 Neuman-Rahn (1924).

44 Om idéinnehåll i denna bok se: Matilainen (1997).

45 B.W. (1925), 21-3. nesnärvaro och ett vänligt ord. Hjälper ett starkt personligt uppträdande icke, tillkallas så många vårdpersoner, som finnas disponibla. Vid åsynen av övermakten lugnar sig vanligen den sjuke, och ingen brottning uppstår, vilket till varje pris måste undgås /.../ Om vi finna den rätta utvägen, kan månget anfall av oro kvävas redan i dess linda eller innan det nått höjdpunkten och övergått i våldsamheter. ${ }^{46}$

Några sjuksköterskor resonerar, som vi sett, om förebyggande strategier utifrån patienternas situation, där våld kunde förstås som rimlig konsekvens av bemötandet på sjukhuset. Patienterna tycktes leva upp till sin roll som potentiellt farliga och personalen svarade med rigorösa säkerhetsrutiner. Sjuksköterskor antyder försök att upprätta nära och förtroendefulla relationer till patienter, som ett sätt att bryta denna onda cirkel som både patienter och personal var indragna i. De tycks ha utvecklat en strategi för kroppsspråk som signalerar icke-våld. Äldre kolleger har varit betydelsefulla förebilder i tillägnandet av denna konst.

Rädslans avgörande betydelse verkar vara ett återkommande tema i samband med potentiell farlighet och våld. Att inte vara rädd uppfattas som en förutsättning för att avstyra våld, eller för att kunna umgås med sinnessjuka personer överhuvudtaget. Att vara rädd beskrivs på ett sätt så det framtonar som våldsframkallande. Detta idéinnehåll om rädslans inverkan på relationen känns också igen från romanerna En herrgårdssägen respektive Sjukdomen.

En herrgårdssägen av Selma Lagerlöf ${ }^{47}$ är till formen en kort roman, men har som

46 Neuman-Rahn (1924), 213-214.

47 Lagerlöf (1967). 
namnet anger karaktär av sägen. Handlingen tilldrar sig på 1830-talet. Sjukdomen av Birgitta Trotzig ${ }^{48}$ har karaktär av historisk roman, med motiv från ett svenskt sinnessjukhus under mellankrigstiden. Båda texterna har karaktär av nedtecknade muntliga berättelser med ett tidsavstånd av några generationer och handlar om en psykotisk ung man, med svåra uppväxtförhållanden, och hans relation till sin vårdarinna. Texterna läses här som projektioner på det förflutna av föreställningar om rädsla i relation till en psykiskt sjuk person.

En herrgårdssägenär en symbolrik berättelse om hur två människor blir varandras möjlighet att återfå livslust och förstånd. "Getabocken" kallades herrgårdsarvingen och studenten Gunnar Hede, sedan han förlorat förståndet och driver omkring i bygden, förvirrad och till åtlöje. Han möter Ingrid Berg, en ung kvinna tyngd av sorg och förtvivlan.

Ingrid får vid ett tillfälle möta en förundrad kvinnas frågor, hur det kunde komma sig att hon inte varit rädd för dåren. "-Å nej, han var inte farlig alls. Inte var han tokig, sade Ingrid, han kunde både köpa och sälja. Han var endast förskrämd «. ${ }^{49}$ Ingrid medger att hon nog varit rädd för honom men tilllägger att han inte var farlig, nästan klok och "han var så snäll«. Ingrid får beröm för sitt mod. »Jag kan förstå detta. Jag kan förstå, att han lydde de ögonen..$^{50}$ säger kvinnan som försöker förstå hur det kan komma sig att Ingrid kunnat umgås med någon som andra undviker. "Lilla vännen måtte verk-

48 Trotzig (1972).

49 Lagerlöf (1967), 64.

50 Lagerlöf (1967), 65. ligen förstå sig på dårar, sade hon. Det är en stor gåva. De flesta är rädda för sådana stackars människor.." ${ }^{51}$

Förtätat förmedlar berättelsen en förståelse av vad som karaktäriserar relationen mellan de två. Dels att den hjälpande personen själv lider och kan dra nytta av relationen för egen del. Dels att dårar går att "förstå sig på» och somliga har den "gåvan". Det kan ha att göra med den personliga utstrålningen, med blicken. En central frågeställning vid samtalet mellan kvinnan och Ingrid är dårens farlighet och om han inger rädsla. Om detta får vi veta tre saker: Han är inte farlig, utan förskrämd, men kan inge rädsla. Budskapet kan tolkas: Det är "dåren« som är rädd. Det kan vara skrämmande att vara i hans närhet, men han är inte farlig.

Romanen Sjukdomen av Birgitta Trozig handlar om den tidigt moderlöse Elje, som lever med sin far. Psykotisk fördes Elje till S:t Lars sjukhus i Lund, som han benämner "apparaten som bättre vet«. ${ }^{52}$ Där härskar en hermetisk avspärrning gentemot det andra könet, det ingick i behandlingen, konstaterar Elje. En »Vakterska» får uppgiften att promenera i parken med Elje. En kväll blir Elje som ett smeksökande litet barn. Men det händer något med hans händer. "De kramade. De måste. De styrde själva." Alldeles plötsligt visste han att en stor olycka hade hänt. Vakterskan låg död, med sönderrivna kläder. ${ }^{53}$ Förmodligen hade hon fått vad hon förtjänat, resonerar Eljes far. Berättelsen

\footnotetext{
51 Lagerlöf (1967), 66.

52 Trotzig (1972), 6.

53 Trotzig (1972), 230-6.
} 
slutar med Eljes egen död »i hjärtstillestånd av skräcku. ${ }^{54}$

Med hjälp av Julia Kristevas teori om abjektet $^{55}$ gör Ebba Witt-Brattström en analys av romanen. ${ }^{56}$ Handlingen tolkas som en faktisk moders frånvaro och hennes symboliska närvaro i en annan kvinnas gestalt. Extra biträdets tafatta, mjuka hand väcker minnen av andra kvinnor som svikit. ${ }^{57}$ Budskapet i romanen kan tolkas som en berättelse om hur en kvinnlig vårdare $\mathrm{i}$ den psykotiske mannens inre värld förvandlas till en modersgestalt och samtidigt en erotiskt laddad kvinna. Besvikelsen blir oundviklig, liksom hatet mot den som väcker förhoppningar och längtan. En nyckel till förståelsen av karaktären i relationen mellan kvinnan och den psykotiske mannen i båda romanerna är rädslans närvaro eller frånvaro. Ingrid försäkrar att hon inte varit rädd som förklaring till att hon kunde umgås med honom som de flesta andra var rädd för. Vakterskans rädsla finns med alltifrån första mötet. »Hon är rädd. ${ }^{58}$

54 Trotzig (1972), 244-5.

55 Kristeva(1991). Se också:Kristeva(1990). Matthis (1992), 117-134.

Begreppet abjektion, liksom teorin om abjektet är skapade av Julia Kristeva utifrån psykoanalytisk och språkvetenskaplig teori. I korthet kan abjektet beskrivas som en psykisk struktur, som avspjälkar och stöter bort modersrepresentationen, så som den mer eller mindre omedvetet framstår från en förverbal tid i utvecklingen. Abjektionen, bortstötandet, riktar sig mot det som samtidigt representerar en attraktiv trygghet och risk för total uppgående $i$ en annan person.

56 Witt-Brattström (1993).

57 Witt-Brattström (1993), 89-115.

58 Trotzig (1972), 217. är den första uppgift vi får om henne. Därefter förmedlas hennes rädsla så substantiellt att det nästan doftar om boken: Rädslan har en särskild lukt, en slags skarp djurlukt. $^{59}$

Vad som ytterligare går att utläsa ur romanerna är de skilda sätt på vilket kvinnorna förmår handskas med sin rädsla. Medan Ingrid i En herrgårdssägen tillstår att personer som Gunnar kan inge rädsla, är det tydligt att hon förmår härbärgera sina egna svåra känslor i relationen. Vakterskan i Sjukdomen överväldigas av sin rädsla, som kan förstås som bidragande till det tragiska slutet i hennes död.

\section{Yrkesidentiteten}

Det är som om sjuksköterskorna undantog sig själva från att ha känt rädsla, annat än som elev. Det är andra som är rädda, patienterochskötare.Sjuksköterskornaintarockså en avståndstagande position till vad de uppfattar som brister ivården och resonerar inte om ett eget ansvar för detta. Det är som om de lastar en opersonlig kulturell tradition för dessa brister, eller andra yrkeskategorier. Jag tolkar sjuksköterskornas berättelser och förhållningssätt som uttryck för yrkesidentiteten, som en självförståelse av vad de upplevt och försökt åstadkomma under sin yrkesverksamhet. Deras utsagor speglar den normativa omvårdnadslitteraturen och de vårdideal som de psykiatriskt verksamma sjuksköterskerskorna såg som sin speciella uppgift att förvalta och sprida vid sinnessjukhusen. Sjuksköterskornas förhållnings-

59 Trotzig (1972), 217-222. 
sätt torde också förstås mot bakgrund av den konkurrenssituation gentemot skötare som rådde vid 1940-talet. Sjuksköterskors tjänstgöring vid sinnessjukhusen kunde vid denna tid uppfattas som hotad. Sjuksköterskor har vid intervjuer vittnat om hur de kände att de oupphörligt måste motivera sin närvaro inom vårdområdet genom att visa sig kapabla. ${ }^{60}$

\section{Välgrundad anledning att vara rädd}

Berättelsen om Elje i Sjukdomen, liksom en välkänd klinisk psykiatrisk erfarenhet, vittnar om vilka projektioner man kan bli utsatt för inom psykiatrisk vård. Det fanns anledning till rädsla, eftersom det förekom våld mot personal, konstaterar också några av sjuksköterskorna i intervjuerna.

I facklitteratur, främst från rättspsykiatri, finns våld beskrivet som ter sig irrationellt och oförutsägbart. Psykiatriprofessor Fredrik Björnström diskuterar 1883 rättsmedicinsk bedömning och hävdar att det högst sällan går att sluta sig till gärningsmannens sinnestillstånd av gärningens blotta art och beskaffenhet, med vissa undantag: ${ }^{61}$

Ofta händer, att en sinnessjuk, manad af en inre oemotståndlig drift, fattar ett mordvapen och blindt rusar på den förste bäste, som råkar komma i hans väg, till och med ett oskyldigt barn, som han icke har minsta anledning att tillfoga något ondt. Härvid är brottet ett rent naturbehof, en slags psykisk konvulsion, hvarigenom en inre oro urladdar sig; efter detsamma

60 Svedberg (1997).

61 Björnström (1883), 12-13. kännes lättnad och lugn; föremålet för brottet var komplett likgiltigt. En sådan handling bär prägeln i sig sjelf. Här kan icke blifva fråga om annat än sinnesrubbning. ${ }^{62}$

Våld som uppfattas som oförutsägbart och okontrollerbart har stor benägenhet att framkalla rädsla, eftersom hotet inte går att förutse och kontrollera. ${ }^{63}$ I nutid återkommer temat, här från enkätundersökning till omvårdnadspersonal inom rättspsykiatrisk vård:

Personal bär på en överhängande känsla, av att de när som helst, utan direkt förvarning kan bli offer för grovt våld. Det kan vara hot om våld mot personal, eller tillbud mot personal och i vissa fall våld mellan patienter. ${ }^{64}$

\section{Vadkan dölja sig bakom rädslan?}

Var det den konkreta rädslan för våld som skrämde, eller kunde det vara en kamouflerad rädsla av psykologiskt ursprung som skrämde? Rädsla kan ha omedvetna orsaker eller vara förknippad med omedvetna föreställningar. ${ }^{65}$ På sinnessjukhuset, där oordning, utbrottavgalenskapochohämmadkänsloutlevelse ständigt hotade, torde ha funnits en rädsla hospersonalen att tappakontrollen. År 1919 publiceras en artikel av Sigmund Freud $^{66}$ som resonerar kring vad som uppfattas som kusligt inom ramen för det som

62 Björnström (1883), 13.

63 Öhman (1991), 48.

64 Rask \& Rahm Hallberg (1997), 84.

65 Rubinstein (1997), 398-400.

66 Freud (1996). 
skapar rädsla och varför det kusliga kan förefalla så lockande. Svaret blev att det kusliga leder till något skräckinjagande som är känt, men bortträngt från medvetandet och som hotar att åter bli medvetet. Det är inte främst det okända som skrämmer, menar Freud, vilket var den allmänna meningen vid denna tid. Freud nämner vansinne bland företeelser som kan förskräcka, med dess yttringar av krafter som man inte väntar sig hos en medmänniska men vars rörelser kan anas i dunkla vrår av den egna personligheten. ${ }^{67}$ Vansinne skulle alltså kunna aktualisera bortträngd skräck för att "gå i bitar", eller impulser att gestalta känslor eller önskningar, som uppfattas som otillåtna att uttrycka eller ens känna. Men samtidigt kan konfrontationen med det problematiska bortträngda locka, i en mer eller mindre medveten strävan efter lindring av de egna kvalen.

\section{Socialt inlärd rädsla}

Föremålen för rädsla varierar betydligt över tid och mellan olika kulturkretsar och har beskrivits som socialt inlärd. ${ }^{68}$ Kulturer skapar myter om vad som är farligt och hur hoten kan hanteras. Dessa kulturella konstruktioner har ofta en grund i reella hot från människans biologiska evolution och har därför vissa genomgående teman. ${ }^{69}$ Rädsla för sinnessjuka är ett sådant tema.

Kvinnor har en inlärd rädsla utifrån föreställningar om hjälplöshet. Det finns fort-

67 Freud (1996), 11.

68 Stattin (1990).

69 Öhman (1994). farande rester av en kvinnoroll, där idealet var den passiva, värnlösa och svaga kvinnan som behövde manligt beskydd. ${ }^{70}$

Kvinnors rädsla har beskrivits som paradoxal, eftersom rädslan kan te sig oproportionerligt stor i relation till riskerna. Denna till synes obefogat stora rädsla har tolkats som en rädsla för sexualbrott som "tillläggsbrott». ${ }^{71}$ Rädsla för fysiskt trauma kan vara förknippat med rädsla för psykologiskt trauma, som förlorad självrespekt eller förlorad respekt från andra personer, risk för social förnedring, att göra bort sig, visa sig svag, maktlös eller förlora sin reella eller symboliska position i sociala hierarkier. ${ }^{72}$ I intervjuerna finns inga omedelbara belägg för sådan rädsla. Men utifrån tolkningen att yrkesidentiteten delvis grundades på förmåga till vissa förhållningssätt, som att avstyra våld genom att inte visa sig rädd, kan våld mot den egna personen få konsekvenser för självbilden och för möjligheten att upprätthålla den auktoritet, som kan vara förknippad med professionen.

\section{En litterärgenre}

Kanske kan skönlitteratur ge en antydan om vad det kan röra sig om för underförstådd eller omedveten rädsla. Romanen Ryggen fri av Rune Pär Olofsson är en historisk roman, som initierat och realistiskt skildrar Säters sjukhus från 1912 och några år framöver. ${ }^{73}$

70 Johannisson (1994). Lindström \& Einerstam (1992).

71 Tiby (1991), 13-26.

72 Rubinstein (1997), 378. Öhman (1994), 59-63.

73 Olofsson (1981). 
Uttrycket »ryggen fri« används huvudsakligen för att beskriva skötares relationer till överläkaren och andra överordnade, mer sällan i kontakterna med patienter. En "medicinsk sköterska" på manlig avdelning utsätts för ett våldtäktsförsök av en patient som hon nekat promenad och som nu tänkte "tukta den satans syster". Hon försätts i en förnedrande situation inför underställd personal, som tänker att "hon hade sig själv att skyllau. ${ }^{74}$ Sjuksköterskan anhöll om förflyttning till kvinnlig avdelning, fick extra betald semester, men återkom inte till sjukhuset. I romanen Gökboet av Ken Kesey ${ }^{75}$ känns intrigen igen från romanen Ryggen fri. »Stora Syster« härskar över manliga patienter och manlig personal. Läkarna beskrivs som frånvarande, kuvadeav sjuksköterskan eller allierade med henne. Enstaka patienter revolterar och försätter sjuksköterskan i förnedrande situationer och utsätter henne för sexualiserat våld. En av medpatienterna, bokens "jag", konstaterade: „Vi kunde inte stoppa honom, för det var vi som fick honom att göra det«. ${ }^{76}$

Det framgår av skildringarna i båda romanerna att dessa övergrepp var förenade med kränkning av en sjuksköterskas fysiska integritet och säkerhet. Hon utsattes för patienters och underställd personals sexuellt laddade blickar och deras underförstådda uppskattning av vad som agerats ut via

74 Olofsson (1981), 154-7.

75 Kesey (1991). Handlingen utspelar sig på ett amerikansk sjukhus något årtionde »efter neuroleptikau. Romanen och de dramatiserade versionerna av den, är så allmänt spridda och uppskattade i Sverige, att de kan anses tillhöra vår kulturkrets myter om mentalsjukhusen.

76 Kesey (1991), 399-403. en patient. Sjuksköterskan försattes i vanmaktsposition, blev förödmjukad och förlorade $i$ auktoritet i relationen till underställd personal. Denna litterära genre kan förstås som fantasier och underförstådda farhågor om vad som kan hända mellan sjuksköterska och manlig patient inom sinnessjukvården. Liksom i de två andra litterära texterna $\mathrm{i}$ ämnet, En herrgårdssägen och Sjukdomen, är det relationen kvinnlig vårdare till sinnessjuk man som problematiseras.

Astrid Lindgren har en variant på temat hur en kvinna i överordnad position inom vården kontrolleras och skräms till underkastelse av män. Kommandoran i Lönnebergas fattigstuga var "en sån mara» och härskade över Stolle-Jocke, Tok-Nicklas, Rackare-Fia,Saliga Amalia och «allt vad de hette». Men livrädd och förödmjukad i »varggropen« ber hon om förlåtelse och erkänner att hon stulit jonens julmat. ${ }^{77}$

Liksom i romanen Sjukdomen finns i litterära skildringar ett återkommande tema, med besked om att den kvinna som råkar illa ut, på något sätt har gjort sig förtjänt av detta. En antydan i samma riktning finns ju också i en av intervjuerna: patienten i sig är inte farlig. Det är miljön och vårt sätt att vara som framkallar oron.

\section{Avslutande kommentarer}

Rädsla har utifrån källorna, i den aktuella kontexten, visatsigvaraettsvårgripbartfenomen, undflyende, mångtydigt och till synes utan större samband med reella hotbilder. Sjuksköterskorna berättar om rädsloföre-

77 Lindgren (1966), 113-156. 
ställningar om patienters farlighet, som tog sig uttryck i föreskrifter, muntligt traderade berättelser och miljöns utformning. Det fanns anledning att vara rädd, men rädslan var mestadels obefogat stor, omvittnar berättelserna. Jag väljer att tolka det som en erfarenhetsbaserad bedömning i relation till den stora rädsla, som framförallt hänförs till vad en nykomling förväntat sig, eller till vad allmänheten antogs föreställa sig. Det är genom realitetsprövning mot verkligheten, som en socialt inlärd rädsla kan få rimliga proportioner. Sjuksköterskors berättelser kan läsas som en dialog med de budskap och föreställningar om rädsla som fanns i sjuksköterskornas miljö på sinnessjukhusen och i litteratur. Källkritiskt kan invändas att det rör sig om relativt få berättelser och att de är retrospektiva. Det finns onekligen viss risk att de ger en alltför idyllisk bild och beskrivning av yrkesverksamheten i linje med det då rådande idealet: att inte vara rädd.

\section{Källförteckning}

Otryckta källor

Intervjuer med 22 sjuksköterskor, verksamma inom svensk psykiatrisk vård före 1953. Intervjuerna gjordes under åren 1982-93. Bandinspelningar och anteckningar, liksom transkriberingar framställda och arkiverade av Gunnel Svedberg.

Riksarkivet:

Medicinalstyrelsens arkiv. Sinnessjukvårdsbyrån. Årsberättelser från sinnessjukhus m. fl. 1942. E II a: 28.

Medicinalstyrelsens arkiv. Sinnessjukvårdsbyrån. Arsberättelser från sinnessjukhus m.fl. 1946. E II a: 32.

Medicinalstyrelsens arkiv. Sinnessjukvårdsbyrån. Årsberättelser från sinnessjukhus m.fl. 1932 E II a:18. Västra Mark, Örebro. Medicinalstyrelsens arkiv. Sinnessjukvårdsbyrån. Överinspektörens berättelser 1932-1933 E II c: 10. Västra Mark, Örebro.

\section{Socialstyrelsen:}

Medicinalstyrelsens arkiv. Sinnessjukvårdsbyrån. Överinspektörens berättelser 1938-1942, E II c: $13 \mathrm{~A}$.

\section{Tryckta källor}

Agerberg, John (1949) „Frösö sjukhus vid Östersund" i Lundquist, G., red: Modern svensk sinnessjukvård Den psykiatriska vården i Sverige förr och nu. Stockholm: AB Modern litteratur.

Bergmann, Sven Arne (1997) Getabock och gravlilja Selma Lagerlöfs En herrgärdssägen som konstnärlig text. Göteborg: Litteraturvetenskapliga institutionen vid Göteborgs universitet, nr 30.

Björnström, Fredrik Joh. (1883) Sinnessjukdomar och abnorma sinnestillstånd betraktade hufvudsakligen frän rättsmedicinsk synpunkt. Stockholm: Konradsbergs boktryckeri.

Bolling, Gustaf (1896) Om användande af sänghvilan för behandling af sinnessjuka. Hygiea, 1-29.

B.W. [troligen Bertha Wellins signatur] (1925) Bokanmälan. Svensk Sjukskötersketidning 1, 21-3.

Crafoord, Clarence (1993) Barndomens återkomst Enpsykoanalytiskoch litterär studie. Stockholm: Natur och Kultur.

Freud, Sigmund (1996) Det kusliga. (original: Das Unheimliche, 1919) Kris 49-50, 3-14.

Gadelius, Bror (1929) Det mänskliga själslivet $i$ belysning av sinnessjukläkarens erfarenhet II. Stockholm: Hugo Gebers förlag. 
Goffman, Erving (1961) Asylums Essays on the social situation of mental patients and other inmates. New York: Doubleday.

Holm, Birgitta (1989) Om Selma Lagerlöf Litteraturtolkning och psykoanalys. Psykoterapi 13, 22-27.

Johannisson, Karin (1994) Den mörka kontinenten Kvinnan, medicinen och fin-de-siècle. Stockholm: Norstedts.

Jönsson, Lars-Erik (1998) Det terapeutiska rummet Rum och kropp $i$ svensk sinnessjukvård 1850-1970. Stockholm: Carlsson Bokförlag. Kesey, Ken (1991) Gökboet. (Original: One Flew Over the Cuckoo's Nest, 1962) Stockholm: Norstedts.

Kristensson Uggla, Bengt (1994) Kommunikation på bristningsgränsen En studie i Paul Ricoeurs projekt. Stockholm: Symposion AB.

Kristeva,Julia(1991) Fasans makt Enessäomabjektionen. (original: Pouvoirs de l horreur. Essai sur l'abjection, 1980) Göteborg: Daidalos.

Kristeva, Julia (1990) Stabat mater och andra texteri urval av Ebba Witt-Brattström. Stockholm: Natur och Kultur.

Lagerlöf, Selma (1967) En Herrgårdssägen. (Första utgåva 1899) Stockholm: Bonniers.

Lindgren, Astrid (1966) Nya hyss av Emil i Lönneberga. Stockholm: Rabén \& Sjögren.

Lindström, Kristina \& Einerstam, Susanna (1992) Rädd för brott. Stockholm: Utbildningsförlaget Brevskolan och BRÅ.

Lundquist, Gunnar (1949a) „Från hospital till modernt sjukhus« i Lundquist, G., red: Modern svensk sinnessjukvård Den psykiatriska vården $i$ Sverige förr och nu. Stockholm: AB Modern litteratur.

Lundquist, Gunnar (1949b) "Medikamentös behandling av psykiskt sjuka « i Lundquist, G., red: Modern svensk sinnessjukvård Den psykiatriska vården i Sverige förr och nu. Stockholm: AB Modern litteratur.

Matilainen, Dahly (1997) Idémönster i Karin Neuman-Rahns livsgärning och författarskap En idéhistorisk-biografisk studie i psykiatrisk vård $i$ Finland under 1900-talets förstahälft. Åbo: Åbo akademis förlag.
Matthis, Iréne(1992) Det omedvetnas arkeologi Om det moderliga. Stockholm: Natur och kultur.

Neuman-Rahn, Karin (1924) Den psykiskt sjuka människan och hennes vård. Stockholm: A.B. Nordiska bokhandeln.

Nyström, Anton (1895) Om sinnessjukdomar och hospitalsvård jämte antydningar om sinnessjukas rättsliga skydd. Stockholm: C.\& E. Gernandts Förlags-Aktiebolag.

Näslund,Hanna Greta(1996)StudieriSelmaLagerlöfs symboliska diktning i slutet av 1890-talet och företrädesvis En Herrgårdssägen. Stockholm: Carlsson Bokförlag.

Olofsson, Rune Pär (1981) Ryggen fri. Stockholm: Norstedts.

Osterman,E.G.E. (1949) „Sidsjöns sjukhus i Sundsvall« i Lundquist, G., red: Modern svensk sinnessjukvaird Den psykiatriska vården i Sverige förr och nu. Stockholm: AB Modern litteratur.

Petherick, Karin (1981) Hur mycket »visste» Ingrid Berg ellerDen halvkvädna visan iSelmaLagerlöfs En herrgårdssägen. Svensk litteraturtidskrift, 1, 37-47.

Rask, Mikael \& Rahm Hallberg, Ingalill (1997) "Rättspsykiatrisk omvårdnad - innehåll och metoderui Innehålloch kvalitet iden rättspsykiatriska vården. Psykiatriuppföljningen 13. Stockholm: Socialstyrelsen.

Ricoeur, Paul (1993)Från text till handling Enantologi om hermeneutik. red: Kemp, P \& Kristensson, B. Stockholm: Symposion AB.

Ricoeur, Paul (1976) Interpretation Theory: Discourse and the Surplus of Meaning. Texas: Christian University Press.

Ricoeur, Paul (1991) „Narrative identity«i Wood, D., red:On Paul Ricoeur: narrative and interpretation. London: Routledge.

Ricoeur, Paul (1992) Oneself as another. Chicago: University of Chicago Press.

Ricoeur, Paul (1988) Time and narrative. Volume 3. Chicago: The University of Chicago Press.

Rubinstein, Benjamin B. (1997) "Hope, Fear, Wish, Expectation, and Fantasy: A Semantic-Phenomenological and Extraclinical Theoretical Study. 1976" i Holt, R., red: Psychoanalysis and the Philosophy of Science. Psychological Issues; 
62/63. Madison, Conn.: International University Press.

Runcis, Maija (1998) Steriliseringar i folkhemmet. Stockholm:

Ordfront.

Sjöström, Bengt (1992) Kliniken taröver dårska pen $\mathrm{Om}$ den moderna svenska psykiatrins fram växt. Göteborg: Daidalos.

Spence, Donald P. (1987) The Freudian Metaphor Toward Paradigm Change in Psychoanalysis. New York, London: W.W. Norton \& Company.

Spence, Donald P. (1982) Narrative Truth and Historical Truth Meaning and Interpretation in Psychoanalysis. New York, London: W.W. Norton \& Company.

Statens sjukhusutredning av år 1943, betänkande IV: Synpunkter och förslag rörande sinnessjukvården. SOU 1948:37.

Stattin, Jochum (1990) Från gastkramning till gatuvåld En etnologisk studie av svenska rädslor. Stockholm: Carlsson Bokförlag.

Svedberg, Gunnel(1997)„Sjuksköterskor på sinnes- sjukhus« iEriksson, B. E. \& Qvarsell, R., red: Hur skall själen läkas? Den psykiatriska vårdens förändringar. Stockholm: Natur och Kultur.

Tiby, Eva (1991) „Kvinna och rädd?» i Wiklund, G., red: Rädslan för brott. Stockholm: BRÅ-rapport 2.

Trotzig, Birgitta (1972) Sjukdomen. Stockholm: Alba.

Witt-Brattström, Ebba (1993) Ur könets mörker Litteraturanalyser. Stockholm: Norstedts.

Qvarsell, Roger (1993) Utan vett och vilja Omsynen på brottslighet och sinnessjukdom. Stockholm: Carlsson Bokförlag.

Öhman,Arne(1991)»Brott och rädsla. Om rädslans psykologi» i Wiklund, G., red: Rädslan för brott. Stockholm: BRÅ-rapport 2.

Öhman, Arne (1994) Rädsla Ångest Fobi. Forskningens frontlinjer. Stockholm: Universitetsförlaget.

Artikeln är en bearbetning av tidigare version, publicerad i Svensk medicinhistorisk tidskriftVol.3 Nr 11999.

\section{Summary Narratives on fear within psychiatric care}

The aim of the study is to describe and analyse beliefs and experiences of mental health care workers within Swedish psychiatric care prior to the introduction of neuroleptics in the early 1950s. The sources are narratives taken from interviews with nurses who worked in Swedish psychiatric care before 1953, works of fiction, and contemporary professional literature. The narratives are discussed from the perspective of modern literature on fear.

A number of themes on fear recur in various permutations. The first encounter with the mentally ill was associated with fear. The physical environment, the regulations and the procedures all sent messages about the potential risks. The choice of psychiatric care as a professional sphere and professional pride alike seem grounded in selfefficacy to overcome fear.

Tall tales and professional literature told of irrational and unpredictable violence among the mentally ill, thus inspiring fear. Violence did occur, but the fear seemed out of proportion to the nurses. The narratives give examples of strategies for dealing with fear, including use of restraints and procedures designed to gain control over dangerous objects and situations. The nurses considered it important to be able to rely on

Socialvetenskaplig tidskrift nr 1-2 • 2001 
co-workers and call for help when necessary. Violence was seen as a consequence of the patient role, where patients lived up to expectations of dangerousness, and nurses tried to develop body language that signalled non-violence, using older colleagues as role models.

Psychological strategies, such as denial of fear or attempts to assimilate fear, are also described. The ability to hide one's fear as a prerequisite for warding off violence and the ability to socialize with the mentally ill in a positive manner are recurring themes in both fiction and contemporary professional literature. The statements are understood as expressions of a normative professional identity in dialogue with the message of fear in psychiatric hospitals.

Implicit or unconscious beliefs about fear are discussed. These include socially learned fear about women's helplessness and need for protection. Fear of physical violence may be related to fear of being put in situations that may entail a threat to one's self-image and the authority associated with nurses' professional identity. 